\title{
Időskorúak életminősége 2008 - 2018
}

\author{
Patyán László ${ }^{1}$ \\ ${ }^{1}$ főiskolai docens, Debreceni Egyetem Egészségügyi Kar, 4400 Nyíregyháza, Sóstói út 2-4.
}

\begin{tabular}{|c|c|}
\hline INFO & ABSTRACT \\
\hline $\begin{array}{l}\text { Patyán László } \\
\text { patyan.laszlo@foh.unideb.hu }\end{array}$ & \multirow{2}{*}{$\begin{array}{l}\text { Quality of Life of the Elderly } 2008 \text { - 2018. This study } \\
\text { examines some aspects of the quality of life of the elderly } \\
\text { people living in Nyíregyháza town. Despite the } \\
\text { methodological difficulties the "Quality of life in Nyíregy- } \\
\text { háza" survey gave us chance to make a comparative } \\
\text { analysis of some elements which determines the life } \\
\text { quality in a perspective of ten year. Results may influenced } \\
\text { by the changes of generations too because these ten years } \\
\text { was enough to find the so called "boomers" in the sample. } \\
\text { Finally results showed better conditions in the objective } \\
\text { indicators of the quality of life such us the subjective, } \\
\text { perceived elements. Future policies may focus more on the } \\
\text { groups living in special needs }\end{array}$} \\
\hline $\begin{array}{l}\text { Keywords } \\
\text { quality of life, } \\
\text { elderly people, } \\
\text { boomers, income, } \\
\text { living conditions, } \\
\text { social connections }\end{array}$ & \\
\hline $\begin{array}{l}\text { Kulcsszavak: életminő- } \\
\text { ség, időskorúak, } \\
\text { boomerek, jövedelem, } \\
\text { lakhatási körülmények, } \\
\text { szociális kapcsolatok }\end{array}$ & $\begin{array}{l}\text { Absztrakt. A tanulmány a nyíregyházi időskorúak életmi- } \\
\text { nőségének néhány összetevőjét vizsgálja meg. A módszerta- } \\
\text { ni nehézségektől eltekintve a 'Nyíregyháza életminősége” } \\
\text { kérdőív lehetőséget biztosított az életminőséget meghatározó } \\
\text { néhány mutató összehasonlító elemzésére tíz év távlatában. } \\
\text { A kutatás eredményeit befolyásolhatta a generációk változá- } \\
\text { sa is, hiszen tíz év elegendő volt egy új generáció a } \\
\text { „boomerek” mintában való megjelenésére. A kutatás ered- } \\
\text { ményei jobb feltételeket mutattak mind az életminőséget } \\
\text { meghatározó objektív indikátorok, mind pedig a szubjektív, } \\
\text { érzékelt mutatók mentén. A szakpolitikák alakítóinak a } \\
\text { jövőben a speciális szükségletekkel rendelkező idősek segí- } \\
\text { tésére, valamint a nagyon alacsony jövedelemmel rendelke- } \\
\text { ző idősek támogatására kell koncentrálniuk. }\end{array}$ \\
\hline
\end{tabular}

Ez a tanulmány a Nyíregyháza város életminősége - Háztartáspanel kutatás Egészségi állapot felmérése keretében készült. 


\section{Bevezető}

Nyíregyháza Város Életminősége kutatás (Fábián és mtsai, 2018) lehetőséget nyújtott arra, hogy a lakosság - ezen belül a városi időskorúak - helyzetét egy évtizeden keresztül kétévente felmérjük. Annak ellenére, hogy a kutatás során a minta választása (Huszti és mtsai, 2018) elveszítette a panel jellegét, azaz nem ugyanazok a háztartások kerültek lekérdezésre, a kutatás értékes eredményekkel szolgálhat a városi időskorú lakosság élethelyzete és életminősége tekintetében.

\section{Egy évtized}

Tíz év jelentős változásokat hozhat a lakosság helyzetében. Nincs ez másként az időskorú lakosok esetében sem. A 65 év feletti népesség esetében egy új kor kohorszt jelent meg a mintában, gyakorlatilag 2008-tól sor került a boomerek idősödésére, vagyis azon korosztályéra, akik a Második Világháború utolsó éveitől kezdve születtek egy olyan időszakban, amikor kiugró volt egész Európában a fertilitási ráta. Elképzelhető tehát, hogy ez az önmagában is nagy korcsoport más értékekkel, elképzelésekkel, életfelfogással, vagy éppen más szociális helyzettel, anyagi státussal rendelkezik.

\section{Demográfiai jellemzők}

2008-ban a válaszadók 15,7\%-a volt 65 évnél idősebb. A KSH városi adatai szerint 2018 - ra a legfiatalabb korösszetételü megye és ezzel együtt a megyeszékhely lakosainak korösszetétele is változott. 2018-ban Nyíregyháza lakossága 120.086 volt és a lakosság 17,6\%-a volt időskorú (KSH, 2018).

Az első felmérés során a minta 376 háztartásában élt hatvanöt évnél idősebb személy. A háztartások 47\%-ában csak időskorúak éltek együtt, vagy egy idős ember élt a háztartásban.

A 2018 évi mintába 104 olyan háztartás került, melyben 65 év feletti személy él. Ez a minta 15,4\%-át jelenti. Az idősek jelentős többsége, mintegy 80\% - a egyedül, egyszemélyes háztartásban, vagy időskorú társával élt. A lakosság demográfiai öregedése tehát Nyíregyházán is érzékelhető annak ellenére, hogy a belső vándorlási folyamatok még mindig fiatalos korstruktúrát eredményeznek.

Az időskorúak iskolai végzettség szerinti megoszlását az alábbi ábra szemlélteti. 


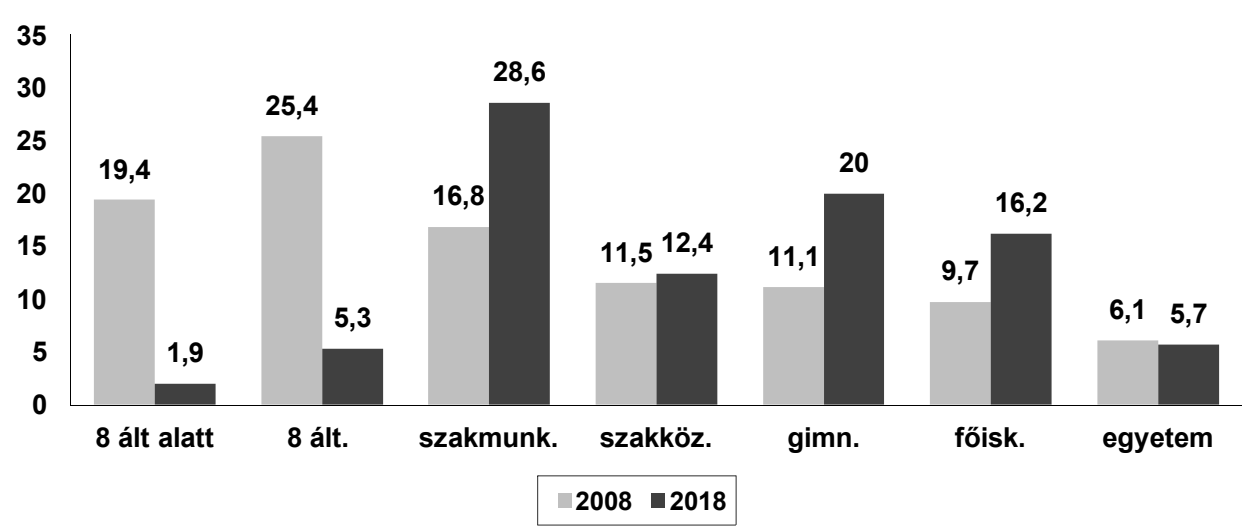

1. ábra: időskorú háztartásfők legmagasabb iskolai végzettség szerinti megoszlása, (2008, 2018).

A 2018 évi kutatás adatai szerint a szakmunkásképzőt végzett idősek száma majdnem megduplázódott csakúgy, mint az érettségizetteké. A föiskolai végzettséget szerzettek aránya szintén jelentős emelkedést mutat. Ez vélhetően a boomerek mintába való belépését mutatja, hiszen ennek a generáció általánosságban magasabb iskolai végzettséget érhetett el a ' 60 -as, ' 70 -es években. A magasabb iskolázottság jobb jövedelmi kondíciókkal kecsegtetett, így az elmúlt évtizedben nyugdíjazottak magasabb járandóságokra is számíthattak.

\section{Jövedelmi helyzet}

Az idősek jólétét meghatározó egyik legfontosabb változó a nyugdíj. Korábban utaltunk az idősek erős nyugdíjfüggőségére (Patyán, 2010), mely a rosszabb egészségi állapot, az alacsony időskori foglalkoztatottság, valamint a korábbi felhalmozások hiánya miatt alakult ki. Idősek jövedelme 2008-ban és 2018-ban a 2. ábrán szemléltetett módon alakult.

Tíz év leforgása alatt gyakorlatilag alig nőtt a 65 év felettiek foglalkoztatási aránya. A munkát vállaló idősek jellemzően teljes munkaidőben dolgoznak, a részidős, rugalmas foglalkoztatási formák elenyésző arányt képviselnek, így lényegesen nem segítik a korosztály munkaerőpiaci részvételét.

Önkormányzati támogatásban - 2008-ban időskorúak járadékában - az idősek alig egytizede részesült 2018-ban. Ez évben nem bontottuk meg a támogatást egyes típusok szerint, de vélhetö, hogy a támogatottak jelentős számban jövedelemkompenzáló ellátásban részesültek.

Még mindig komoly eltérés mutatkozik az átlagnyugdíjak tekintetében, melynek eredményeként a megyében lehet a legalacsonyabb átlagnyugdíj értékeket találni. Ennek oka a korábbi foglalkoztatási státus és jövedelem különbségeiben keresendő, de megyénkben él a legtöbb nem saját jogú öregségi nyugdíjban részesülő időskorú is, az alacsonyabb összegú járandóságok aránya pedig lehúzza a nyugdíjátlagot. 


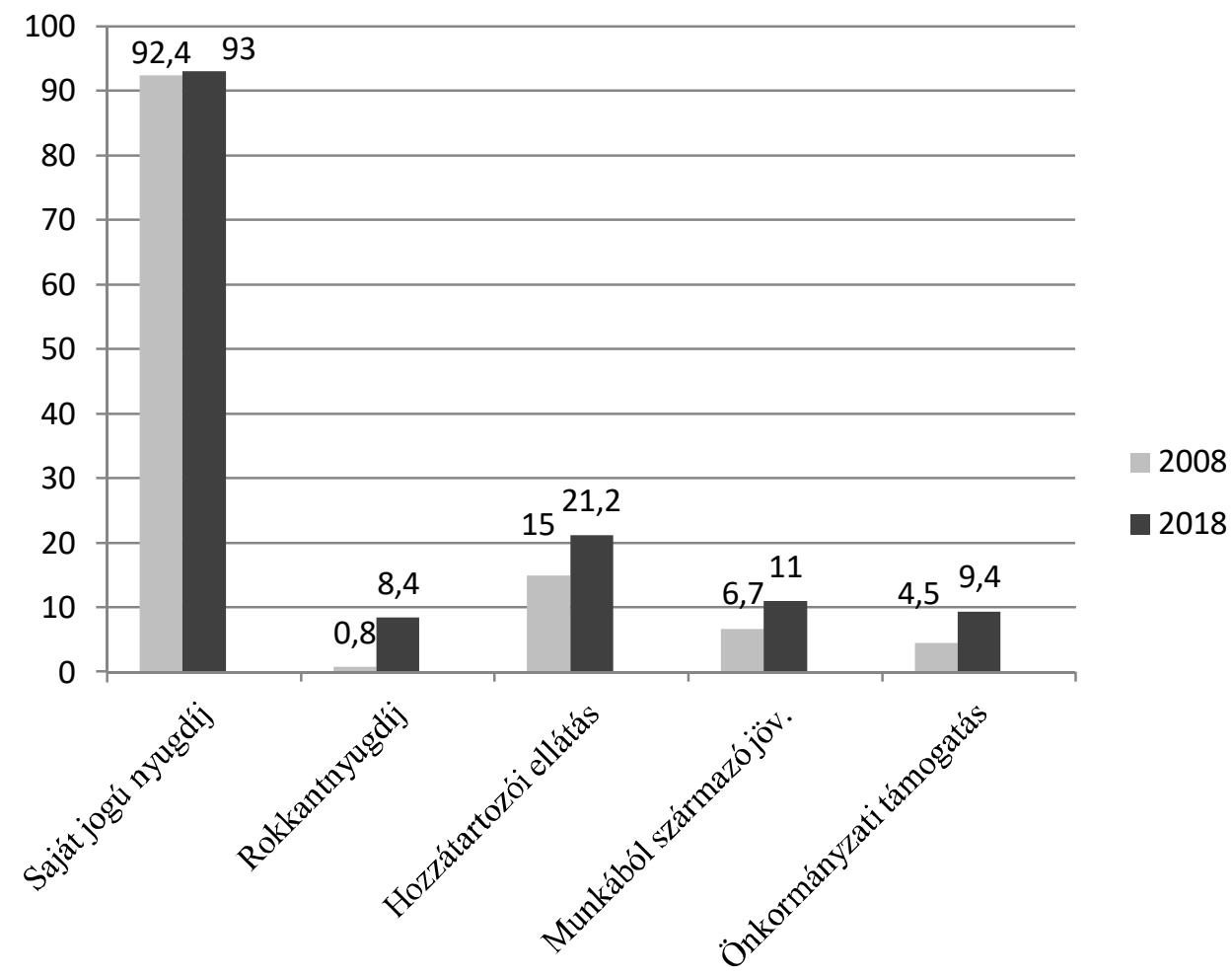

2. ábra: Időskorút tartalmazó háztartások megélhetését biztosító jövedelemtípusok megoszlása 2008-ban és 2018-ban Nyíregyházán (\%).

Ezek az egyenlőtlenségek egy évtized alatt mit sem változtak, sőt inkább nőttek. 2008-ban a nyugdíjak országos átlaga 78.897 Ft volt, addig Budapesten a havi átlagnyugdíj összege 92.400 Ft volt, Szabolcs - Szatmár - Bereg megyében pedig mindössze 60.100 Ft-ot kaptak átlagosan a nyugdíjból élők. 2018-ban 39.000 Ft-al volt alacsonyabb az átlagnyugdíj Szabolcsban, mint a legmagasabb nyugdíjátlagot képviselö Budapesten. (BP: 154.000 Ft, Sz-Sz-B megye: 115.000 Ft) (KSH, 2018). A nyugdíjak eloszlása tehát meghatározó tényező lehet és annak ellenére, hogy a nyugdíj maga nem jelent akkora szegénységkockázatot, mint a munkanélküliség, a nyugdíjminimum környékén élök komoly szegénységkockázatnak vannak kitéve.

A KSH 2015 évi felmérése alapján (KSH, 2018) az idősek szerint 79.500 Ft egy före eső havi támogatás nagyon szükös megélhetést biztosít számukra. Megfelelő anyagi feltételeket $272.200 \mathrm{Ft}$ egy före eső havi nyugdíj jelentene. Az életkor előrehaladtával a kívánatos megélhetést biztosító összeg némileg csökkent, de még a 70 év felettiek is 270 ezer forint fölötti havi összeget tartanak kívánatosnak.

2018-ban összesen 91 ezer nyugdíjas kapott 60.000 Ft-nál alacsonyabb nyugdíjat hazánkban, ez a nyugdíjasok 4,5\%-át jelenti (KSH, 2018). A háztartáspanel kutatás eredményei szerint városunkban a 65 év feletti lakost tartalmazó háztartások 13,6\%ában alacsonyabb az egy före eső jövedelem 60.000 Ft-nál.

Mindezek ellenére az időseket tartalmazó háztartások jövedelemi kvintilisei az alábbiak szerint alakultak 2008-ban és 2018-ban. 


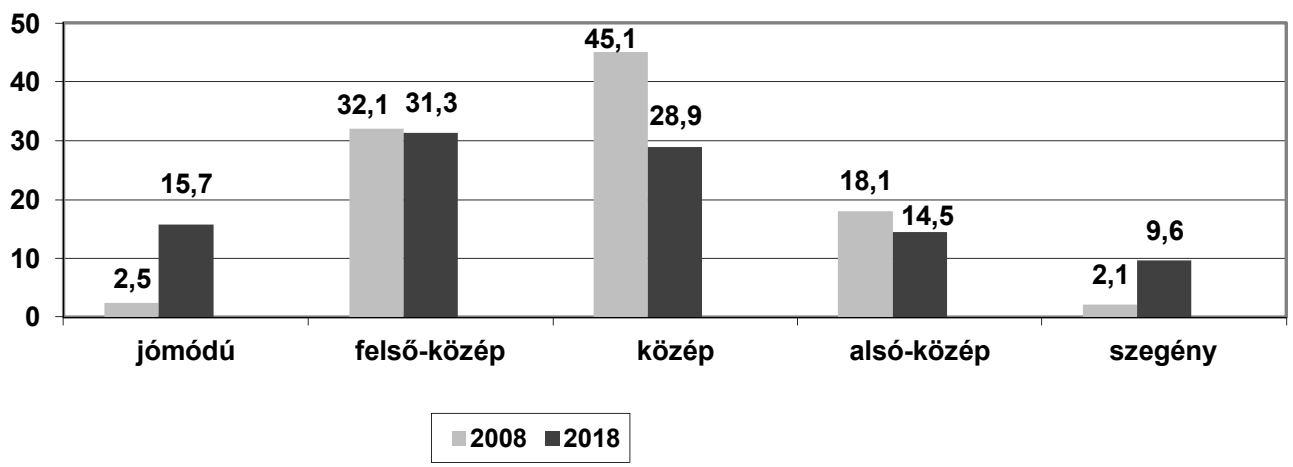

3. ábra: Jövedelmi kvintilisek a háztartási jövedelmek alapján (egy főre jutó jövedelem medián értékének százalékában).

2008-ban azt feltételeztük (Patyán, 2010), hogy az idősek anyagi helyzete a következő évtizedben negatív irányba fog változni a járulékfizetésből kiszorult népesség elöregedése következtében. Az országos adatok ismeretében megállapítható, hogy a nyugellátásból kiszoruló és időskorúak járadékát kapó idősek száma nem emelkedett, sőt inkább csökkenőben van (KSH, 2017). Adataink alapján a 2018 évi mintába került idősek körében némiképp nőtt a legalsó jövedelmi kvintilisbe tartozók aránya és nőtt a legfelső jövedelmi csoportba tartozók aránya is. Ennek magyarázata a kisnyugdíjasok relatív lefelé csúszása lehet, aminek az oka a jövedelmek kisnyugdíjak mértékét meghaladó emelkedése az elmúlt évtizedben, míg a nagyon jó anyagi helyzetben lévők arányának emelkedését valószínüleg az elmúlt évtizedben nyugdíjba vonult időskorú lakosság relatíve magasabb nyugdíja indokolja.

A nyugdíjból élők anyagi státusának „szétcsúszása” az alacsony nyugdíjból élők speciális jövedelemkompenzációjának szükségességére hívja fel a figyelmet, melyet a nyugdíjbiztosítás elmulasztott megtenni az elmúlt évtizedben, így a települési önkormányzatok felelőssége fokozódik a kisnyugdíjasok támogatásában. (4. ábra)

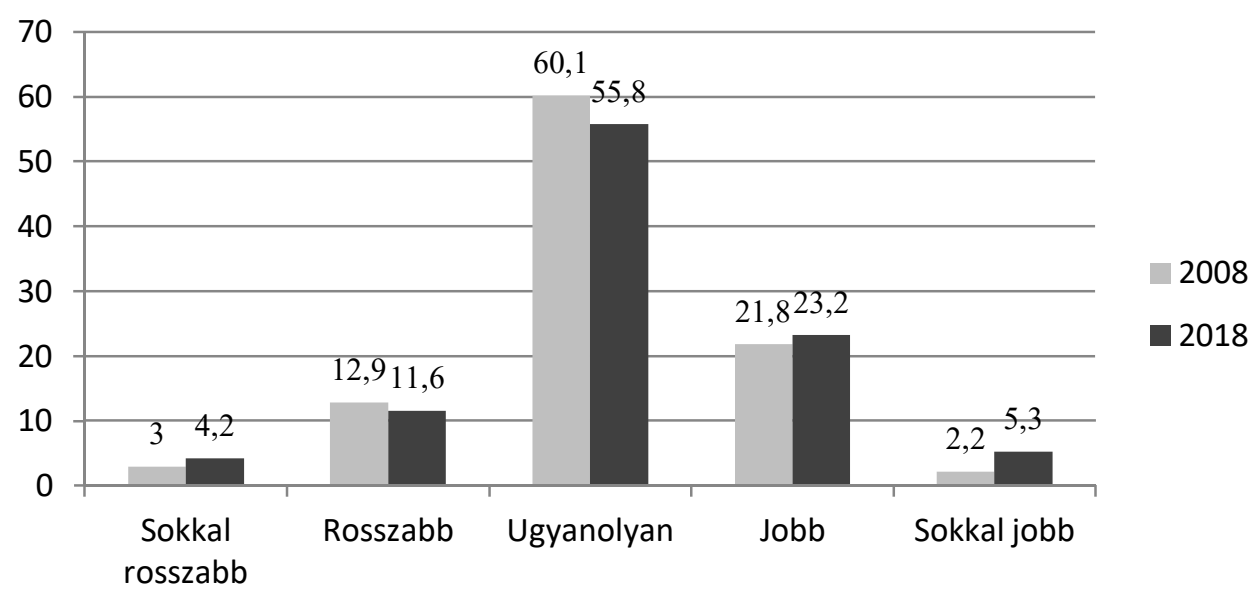

4. ábra: Az idősek szubjektív önbesoroláson alapuló értékelése a saját helyzetének megítélésében 2008-ban és 2018-ban. 
Mindettől függetlenül az idősek szubjektíve kedvezőbbnek ítélik meg helyzetüket, legalábbis kismértékben nőtt azok aránya, akik jobbnak, vagy sokkal jobbnak élik meg helyzetüket más hasonló korúhoz képest.

\section{Lakás, lakókörnyezet}

Az idősebb korosztály mobilitási hajlandóságáról a 2008 évi kutatási hullámban beszámoltunk (Patyán, 2010). Az időskorúak életében a költözést számos kényszer indukálhatja. Az egy évtizeddel korábban készült kutatás eredményei szerint az idősek 15,1\%-a költözött 60 éves kora után. A mobilitás legfontosabb okai között az egészségi állapot romlását, a gyermekekhez közelebb költözést, a lakókörnyezet problémáit, a biztonság hiányát, vagy ezek kombinációit találtuk. A KSH által 2015ben készített „Lakáspiaci életutak” c. kutatás eredményei szerint (Székely, 2017) az országban az idősek 25\%-a rossz lakásban él, a lakás alacsony értékü és/vagy rossz állapotban van. A megyeszékhelyeken rossz lakásban élő idősek 22,5\%-a lakótelepi lakásban él. Az egyedül élők harmada (32\%) él rossz lakásban. Mindezek ellenére az idősek 90\%-a elégedett lakáskörülményeivel. Az idősek 4,8\%-a nyilatkozta, hogy az elkövetkező években szeretne költözni. 32\%-uk úgy véli, hogy ha költözésre kerülne a sor, akkor gyermekeihez szeretne leginkább közelebb költözni.

A 2018-ban megkérdezett idősek 16,3\%-a költözött 60 éves korát követően. A minta fiatalabb korosztályaihoz képest, ahol ez az érték mindössze 9,7\% ez - a tíz évvel korábban készült felmérés eredményéhez hasonlóan - kiemelkedő arány. Tíz év alatt alapvetően nem változott a lakások állapotának megítélése sem. Minden ötödik idős szerint van a lakásának olyan problémája, ami nehezíti a napi életvitelt.

A lakás megfelelőségét 2008-ban jellemzően a fenntartási költségek befolyásolták. Akkor az idősek 42\%-a nyilatkozta, hogy nagyon megterhelő a lakás fenntartása, ami a magas költségek mellett az idősek által lakott lakások relatív nagyságával volt magyarázható (Patyán, 2010). 2018-ban az idősek fele két szobás, 36\%-a három, vagy négy szobás lakásban él. A lakások harmada 51 - 60 négyzetméteres, harmada 61 - 80 négyzetméter között van. Tekintettel arra, hogy az idősek 80 \%-a egy vagy kétszemélyes háztartásban él, a lakhatás terhei magasak lehetnek. A KSH 2005 - 2015 években készült felmérése szerint az időskorúak továbbra is jelentős összeget költenek lakásfenntartásra annak ellenére, hogy a vizsgált időszakban a közüzemi költségek csökkentek. Ennek egyik oka, hogy ennek arányában több helyen nőttek a bérleti költségek, valamint az idősek többet fogyasztottak az energiahordozókból (KSH, 2018).

Tíz éve még az idősek 55,6\%-a nyilatkozott úgy, hogy problémát jelent számára a lakás megfelelő fütése, 2018-ban a válaszadók túlnyomó többségének (92,2\%) ez már nem okozott nehézséget. A nagyobb kiadások, mint a lakás felújítása a 2018 évben megkérdezettek 40\%-ának nem okozna gondot. Az idősek esetében minden harmadik válaszadó tudna megbírkózni egy nem tervezett nagyobb kiadással. Ennek megfelelően az idősek 45\%-a tudta lakását felújítani az elmúlt öt évben, míg a fiatalabbak kétharmada tudott ilyen kiadásokat finanszírozni. 
Összességében megállapítható, hogy tíz év leforgása alatt csökkent az idősek lakhatással kapcsolatos anyagi függősége. Lakásaik állapota rosszabb, valamint az arra fordítható költségek az átlag háztartásokhoz képest nehezebben mobilizálhatók, de ez szubjektíve kevésbé okoz problémát az időskorú lakosságnak. A megélhetéssel kapcsolatos vélekedések átlagai az ötödik ábrán láthatók (ötfokozatú skála).

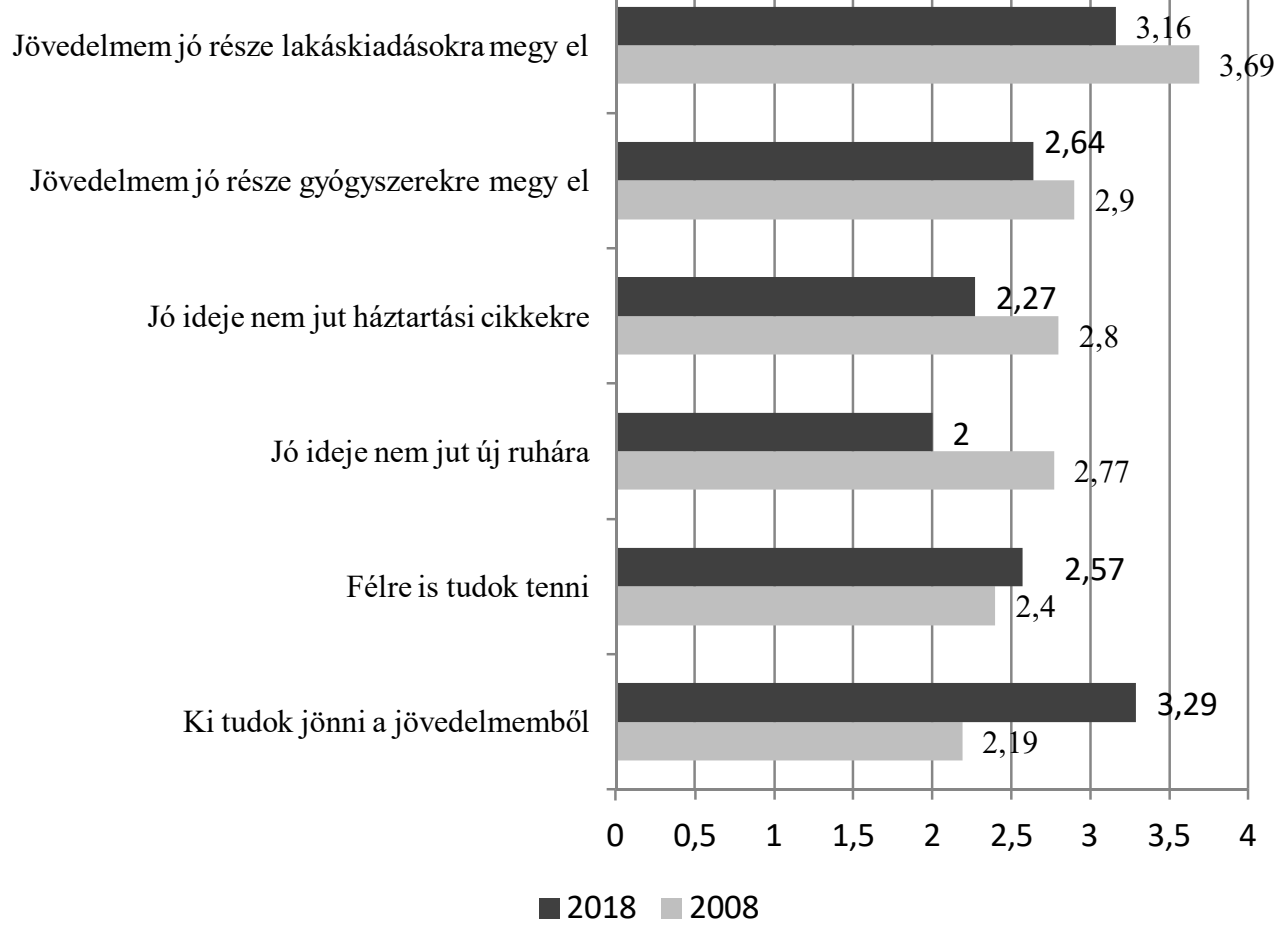

5. ábra: Idősek megélhetéssel kapcsolatos vélekedéseinek átlagai ötfokozatú skálán 2008, 2018.

\section{A háztartások felszereltsége}

A háztartások felszereltsége lényeges változáson ment át egy évtized alatt. Úgy is mondhatnánk, hogy 2008-ban az aktív korosztályra jellemző mutatókat találjuk 2018-ban az időskorúak esetében. A mosógép, mobiltelefon, mikrohullámú sütő, hütőszekrény ma már szinte minden háztartásban megtalálható. 2008-ban az időskorú háztartásfők 15,6\%-a nyilatkozta azt, hogy van Internet hozzáférése lakásában, ez 2018-ra 94,2\%-ra nőtt, melyből 37,6\% szélessávú Internetet használ. Az asztali számítógépek mellett megjelent a laptop (73\%) de mindezek ellenére, a közszolgáltatásokról jellemzően még nem a Neten keresztül tájékozódnak az időskorúak. Tíz év alatt duplájára nőtt azok száma, akiknek a háztartásában személygépkocsi is van. (6. ábra) 


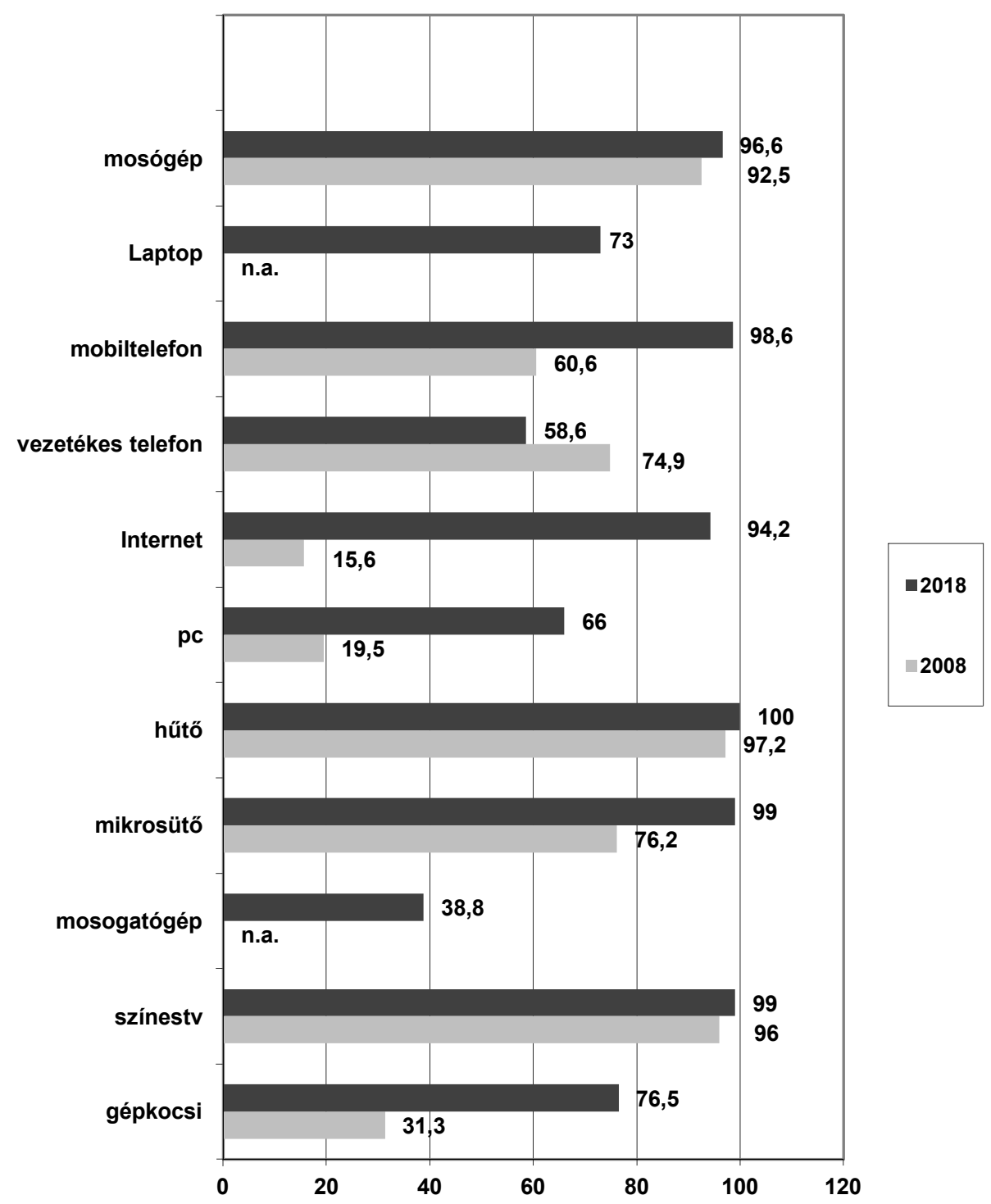

6. ábra: Az időskorút tartalmazó háztartások felszereltsége 2008, 2018

\section{Támogatás, segítségnyújtás}

A támogató rendszert természetesen még mindig a család vezeti az idősek esetében is. Az időskorúak az aktív népességtől is jobban támaszkodnak a családtagok segítségére (94,5\%). A korábbi évekhez képest jelentősen nőtt azok száma, akik barátaikra is támaszkodnak, ha segítségre van szükségük (48,5\%). Ismerőst $25 \%$ jelölt meg.

Korábbi kutatásaink eredményei szerint az életkor előrehaladtával csökken a barátok száma, nő az esély az időskorúak izolációjára. A kapcsolatok minősége is 
megváltozik, nő a fizikailag közel élő emberek szerepe, így az idősek egyre többen a szomszédot tekintik barátjuknak (Patyán 2015) (Huszti, 2015). A barátok száma a nyugdíjba vonulással, a fizikai kondíciók romlásával valamint a gondozásra szorulással arányosan csökken, a megmaradó kapcsolatok jelentősége felértékelődik az idősek életében. (7. ábra)

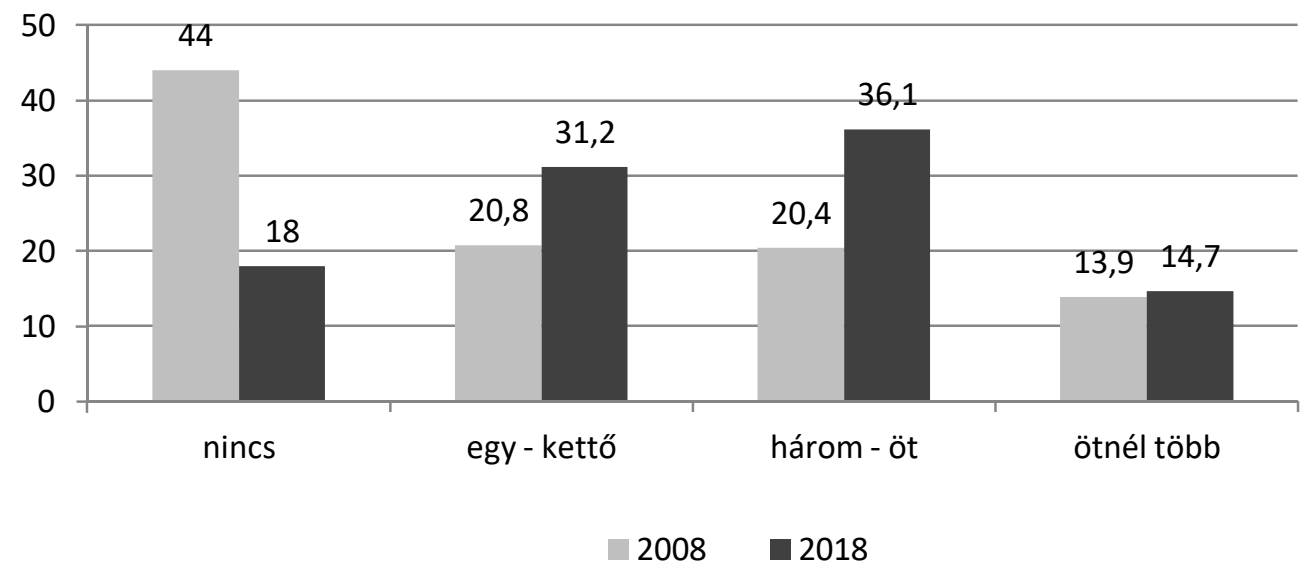

7. ábra: Időskorú városi lakosok barátainak száma 2008, 2018.

2008-ban az idősek 40\%-a egy - két barátról számolt be, de probléma esetén azonban csak minden ötödik idős fordult volna barátjához segítségért. Úgy tünik tehát, hogy a 2018 évi lekérdezés során egy, a baráti kapcsolatokra inkább támaszkodó mintát találtunk kutatásunk során.

$\mathrm{Az}$ intézményekbe vetett bizalom ezzel szemben alacsonyabb a teljes mintában tapasztalt arányhoz képest. A járási hivatalban 10,3\%, az önkormányzatban 16,7\% lát segítséget, míg szociális intézményekre 17,9\% számít. Ezzel szemben a vizsgált évben az idősek 4\%-a fordult a Polgármesteri Hivatalhoz, 2,8\%-uk pedig a Járási Hivatalhoz segítségért. Az intézményekről, valamint az igényelhető segítségekről általánosságban a családtól és ismerősöktől szereznek információkat $(66,7 \%)$, alig ötödük a sajtóból informálódik.

A mintába került idősek 14,2\%-a szorul gondozásra saját megítélésük szerint. Kétharmadukat a családtagok segítik, gondozzák, harmaduk intézményi gondozásban (is) részesül. A formális gondozás jelentős részét egyházi szolgáltatóktól kapják, az önkormányzat saját intézményei a mintába került idősek mindössze $5 \%$-át látják el. Ez az arány a hazai szolgáltatási formák lefedettségéhez képest az országos átlag körüli, mivel országosan az idősek mintegy 11\%-a kap gondozást valamilyen formális szolgáltatáson keresztül és a gondozást kapók mintegy kétharmada otthon közeli gondozásban részesül (Jeneiné Rubovszky, 2017) (Patyán, 2018). Az idősek alapjában elégedettek a gondozással (mean: 4,13), akik nem, azok jellemzően a gondozás intenzitását érzik kevésnek (hétvégén, ünnepeket, valamint a nap 24 órájában szeretnének megfelelő gondozást kapni).

Az idősek formális rendszerekkel való kapcsolatát számos tényező befolyásolja. A korábbi hazai kutatások szerint jellemzően azok az idősek jutnak több informáci- 
óhoz az ellátásokról, szolgáltatásokról, akik aktív élő családi támogatórendszerrel rendelkeznek (Patyán - Fábián, 2014). A közigazgatás korszerüsödése és az ennek érdekében tett szükségszerü átszervezések nehézkessé tehetik az idősebb korosztály számára a szociális igazgatási rendszer átlátását. A közigazgatás új formái (pl. eügyintézés) az idősek egy részét komoly kihívás elé állíthatja a közeljövőben. A szolgáltató rendszer centralizálódása és egyidejü pluralizálódása ugyancsak nehézségeket okozhat (Krizsai - Tóthné Csatlós, 2015). Az otthon közeli gondozást jelenleg az önkormányzaton kívül számos egyéb szolgáltató biztosítja, melyek közül kapacitását tekintve mindenképpen ki kell emelni az egyházi szolgáltatókat, amelyek az otthon közeli gondozási kapacitások jelentős részét vállalják. Az önkormányzatok koordinációs funkciójának gyengülésével azonban nagyon nehéz átlátni az elérhető szolgáltatásokat, az önmaga ellátásra nem képes és megfelelö természetes támasz nélkül élő idősek kirekedhetnek a szolgáltatásokból.

A nemzetközi trendeket igazolva a gondozást kapók jelentős része a család támogatására számíthat (OECD, 2011). A családi gondozást erősítő szolgáltatások növelhetik a bizalmat a formális rendszerekkel kapcsolatban, nagyobb biztonságot nyújtanak az időskorúnak és a gondozójának egyaránt (Triantafillou és mtsai, 2011). A méltányossági ápolási díj 2015-től történő kivezetésével Magyarországon mintegy 10.000 gondozó támogatása szünt meg és most nehéz követni, hogy hány idősgondozó családtag kap segítséget az önkormányzatoktól. Nyíregyháza városban a települési támogatás részeként továbbra is lehet igényelni ápolási díjat, melyhez a helyi rendelet szerint gondozási képzést, tanácsadást is szervez a helyi szolgáltató.

A formális rendszerek jövőbeni kihívása tehát az lesz, hogy miként tudja elérni és célzott eszközökkel támogatni azokat az időskorúakat, akik anyagi helyzetük, önellátó képességük, vagy egyéb speciális ok miatt (pl. demencia) kiemelt figyelmet és gondozást igényelnek. Az ellátási felelősség ugyanis a fentiek ellenére még mindig az önkormányzatot terheli.

\section{Időskori aktivitás}

A közösségi, szomszédsági kapcsolatok, a társadalmi részvétel alapvető szerepet tölt be az időskori aktivitás megőrzésében. Egy évtizeddel korábban az idősek alacsony aktivitásáról számoltunk be e téren. Alig minden harmadik időskorú volt tagja valamilyen sportklubnak, vagy szomszédsági csoportnak. A közösségi aktivitás mértéke tíz év alatt lényegesen nőtt. (8. ábra)

Megállapítható, hogy 2018-ban a mintába került idősek társadalmi aktivitása szinte minden vizsgált dimenzióban meghaladta az egy évtizeddel korábbi értékeket. Kiemelkedő érdeklődés mutatkozik a vallási közösségekhez tartozás iránt, az eredmények szerint majd' minden harmadik időskorú nyilatkozott úgy, hogy vallási közösség tagja. Ez az arány mintegy ötszöröse az aktív korosztály körében talált rátának.

A müvészettel foglalkozó közösségekhez való tartozás aránya mindegy ötszörösére nőtt, a jótékonysági szervezethez tartozás pedig duplájára a hivatkozott korábbi felmérés során talált értéknek. Figyelemreméltó továbbá, hogy a megkérdezettek mintegy ötöde rendszeresen vesz részt városi rendezvényeken. 


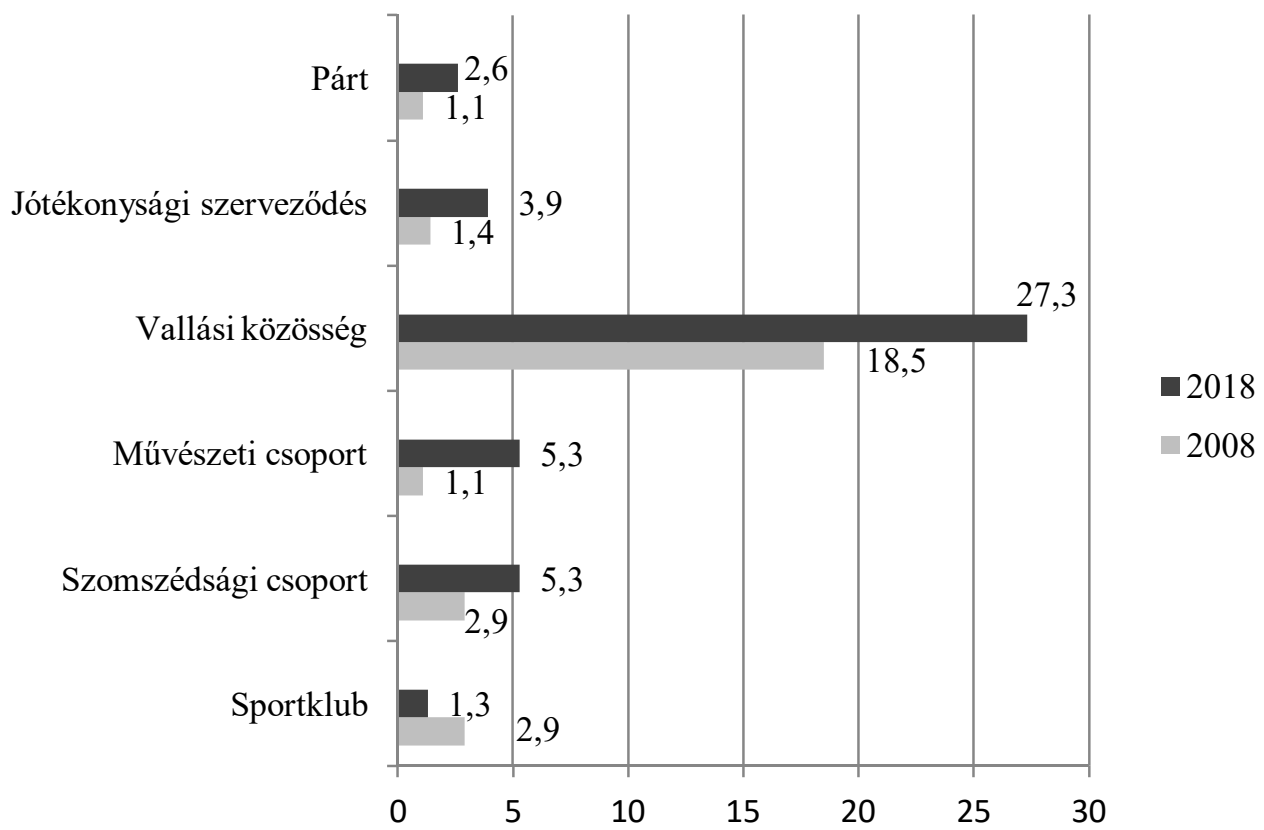

8. ábra: Idősek társadalmi részvételének egyes mutatói Nyíregyházán 2008, 2018.

A városi időskorúak növekvő társadalmi aktivitása nagyon fontos jelenség, mely az idősekkel kapcsolatos gondolkodásmód, a helyi időspolitikák alakítása szempontjából is kihívásokat tartogat. A kutatás tapasztalatai szerint a mai időskorúaknak mások a közösséggel, társadalmi részvétellel kapcsolatos preferenciáik, szükségleteik, melyeket megfelelő módon csatornázva az időskorú polgárok javíthatják saját életminőségüket és értékes erőforrásai lehetnek a közösségnek, a helyi társadalomnak.

\section{Összegzés}

Tíz év leforgása alatt a városban élő idősek egy új korcsoportja került a 65 év felettiek táborába. E csoport - ha a minták eseteges eltéréseit figyelmen kívül hagyjuk magasabb iskolai végzettségü, jobb kapcsolati hálóval rendelkező korcsoport, melynek aktivitása felülmúlja a tíz évvel korábban e korcsoportban talált lakosságét.

Az idősek megélhetése, a lakás fenntartásával kapcsolatos kondíciói némiképp javultak, mely a minta jobb jövedelmi helyzetével és a lakásfenntartás alacsonyabb költségeivel is magyarázható. A KSH kutatásai szerint az idősek a kedvezőbb feltételekre több fogyasztással reagáltak, ezért csökkent a lakás fenntartásán spórolók aránya. A háztartások felszereltsége lényeges változáson ment keresztül. A használati eszközök közül kiemelendő a mobiltelefont, az Internetet, valamint a személygépkocsit használók arányának emelkedése, hiszen ezek az eszközök segíthetik az időskorú tájékozódását, mozgását, információkhoz, kapcsolatokhoz és szolgáltatásokhoz való hozzáférését. 
A foglalkoztatás mutatói a korosztályban még mindig igen alacsony értékeket mutatnak, a foglalkoztatási struktúrában hiányzik a részidős, rugalmas foglalkoztatás lehetősége, mely több időskorút tarthatna a munkaerőpiacon.

A hivatalok és közszolgáltatások irányában alacsonyabb a bizalom, mint az aktív korosztály körében. Az idősek háztartásának technikai felszereltsége nem eredményezi automatikusan a szolgáltatások jobb hozzáférését. Az idősek a közszolgáltatásokkal kapcsolatban még mindig a „régi módon” szereznek információkat, főképp családjuktól, ismerőseiktől.

Eredményeik az időskorúakkal kapcsolatos helyi stratégiák, valamint szakpolitikák két nagy irányvonalát hangsúlyozzák.

Az első az aktív idősödés segítő helyi politikák közép - és hosszú távú fenntartására irányulnak. Nyíregyházán az utóbbi években számos olyan program indult, mely az idősek társadalmi és politikai részvételét segítette elö, a közösségi részvételt segítette, valamint az idősek egészséges életmódjának fenntartását erősítette. A közösségi programokra nyitottabb idősek esetében vélhetően ezek az erőfeszítések is támogatták korosztály közösségi részvételét így ezen programok fenntartása, segítése és a helyi települési stratégiákkal való szerves integrálása a jövőben komoly hatással lesz az idősek életminőségére. Az aktív idősödést segítő települési programok hazánkban még kevésbé koordináltak, azok jószerivel a települések erőfeszítésein alapulnak. A hazai jó példák (pl. Újbuda $60+$ program) figyelembe vétele mellett azonban látható, hogy a korosztály további bevonására a tevékenységek további színesítésével lehet esély.

A szakpolitikák másik fejlesztési iránya a település koordinációs és szolgáltatásfejlesztő szerepének fejlesztése lehet. Az ellátási kötelezett önkormányzatnak fontos feladata a szolgáltatások átlátható koordinálása, a szolgáltatók közötti együttmüködés fejlesztése annak érdekében, hogy az alacsony jövedelemmel rendelkező, vagy szociális helyzete, izolációja, egészségi állapota miatt a szolgáltatásokból való kiszorulás veszélyében élő időskorúakat megfelelően segítse a településen elérhető szolgáltató rendszer.

\section{Irodalomjegyzék}

1. Ezüstkor - Időskorúak a társadalomban 2015. Kiadja: KSH Budapest, 2018.

2. Fábián G., Huszti É., Hüse L., Takács P. (2018): Életminőség Nyíregyházán. A nyíregyházi nagymintás társadalomkutatások első négy hulláma a megyeszékhelyen. Szabolcs-Szatmár-Beregi Szemle 53/3: 83-102.

3. Huszti Éva (2015): Mondd meg kikkel töltöd az idődet és megmondom ki vagy. A társas támogatást nyújtó személyes kapcsolati háló néhány jellemzője és müködése a Nyíregyházi járásban ACTA Medicina et Sociologica vol. 6. no 18 19. 121 - 145. o.

4. Huszti Éva, Hüse Lajos, Takács Péter, Fábián Gergely, (2018): A „Nyíregyháza Élet-minősége 2018" vizsgálat és a kutatás módszertana. Acta Medicinae et Sociologica Vol.9. No.27. 7-18. 
5. Jeneiné dr. Rubovszky Csilla (2017): Az idősgondozás megoldatlanságának áldozatai. A gondozó családok helyzete a mai Magyarországon (Doktori diszszertáció ELTE TáTk)

6. Krizsai Anita - Tóthné Csatlós Ildikó (2015): Szociális problémák és a segélyezési rendszer átalakulása a Nyíregyházi járás területén. ACTA Medicina et Sociologica vol. 6. no 18 - 19. 181 - 197. o.

7. OECD: Help wanted? Providing and Paying for Long Term Care Chapter 4. Policies to Support Family Carers http://www.oecd.org/els/health-systems/helpwanted-9789264097759-en.htm Letöltés ideje: 2017. 06. 12.

8. Patyán László (2010): Időskorúak Nyíregyházán, Szabolcs - Szatmár - Beregi Szemle 2. 237 - 254. o.

9. Patyán László (2012): Időskorúak életminősége 2010. in: Életminőség Nyíregyházán 2008 - 2010. (szerk: Fábián - Patyán - Huszti) DE EK, Nyíregyháza ISSN 2063-3572 117- 135.o.

10. Patyán László (2015): A nyíregyházi járásban élő idősek életkörülményei ACTA Medicina et Sociologica vol. 6. no 18 - 19. 162 - 181. o.

11. Patyán László (2018): A professzionális és családi gondozók viszonyrendszere az idősek otthoni gondozásában (Doktori disszertáció ELTE TáTk)

12. Székely Gáborné (2017): Lakáspiaci életutak in. Giczi Johanna (szerk): Ezüstkor: korosodás és társadalom KSH Budapest, $18-28$. o.

13. Triantafillou, Judy - Naiditch, Michel - REPKOVA, Kvetoslava - Stiehr, Karin - Carretero, Stephanie - Emilsson, Thomas - Di Santo, Patrizia - Bednarik, Rastislav - Brichova, Lydia - Cerruzi, Francesca - Coredo, Laura Mastooyiannakis, Tasos - Fernando, Maite - Mingot, KARL - Ritter, Joachim - Vlantoni, Diamantoula (2011): Informal care in the Long Term Care system. Executive summary. European Comission, Wien http://interlinks.euro.centre.org /project/reports, 2017. augusztus 10.

Webes források:

KSH Jövedelempótló szociális juttatások 2000 - 2018.

http:/www.ksh.hu/docs/hun/xstadat/xstadat_eves/i_fsp010b.html 